\title{
HUNTING PRACTICES AND ENVIRONMENTAL INFLUENCE: A BRIEF OVERVIEW WITH AN ETHNOZOOLOGICAL APPROACH
}

\author{
José Aécio Alves Barbosa ${ }^{*}$, José Otávio Aguiar², Rômulo Romeu da Nóbrega Alves ${ }^{3}$
}

${ }^{1}$ Programa de Pós-Graduação em Recursos Naturais, Centro de Tecnologia e Recursos Naturais, Universidade Federal de Campina Grande

${ }^{2}$ Centro de Humanidades, Universidade Federal de Campina Grande

${ }^{3}$ Departamento de Biologia, Centro de Ciências Biologicas e da Saúde, Universidade Estadual da Paraíba

*Autorpara correspondência: barbosa.joseaecioalves@gmal.com

Recebido em 23 de maio de 2018. Aceito em 20 de dezembro de 2018. Publicado em 28 de dezembro de 2018.

\begin{abstract}
Aвstract - Wild animal hunting is still a recurring practice around the world, being motivated by multiple factors and being directly related to cultural and environmental aspects. Due to the wide range of possible approaches to the subject of hunting, ethnozoology seeks to understand it under an interdisciplinary approach, considering related historical, ethical, social, economic, cultural and environmental aspects. This justifies its importance as a conservation tool. Thus, this article is part of a heuristic investigation and seeks to synthesize the main considerations about hunting and its dynamism.
\end{abstract}

Keywords: Hunting PRACTICES, Interdisciplinarity, WiLDLIFE ConSERVATION.

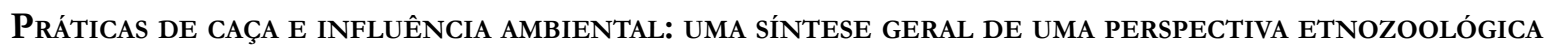

Resumo - A caça de animais silvestres ainda é uma prática recorrente em todo o mundo, sendo motivada por múltiplos fatores e estando diretamente relacionada aos aspectos culturais e ambientais. Devido à ampla gama de abordagens possíveis para o tema da caça, a etnozoologia procura entendê-lo sob uma abordagem interdisciplinar, considerando aspectos históricos, éticos, sociais, econômicos, culturais e ambientais relacionados. Isso justifica sua importância como ferramenta de conservação. Assim, este artigo faz parte de uma investigação heurística e busca sintetizar as principais considerações sobre a caça e seu dinamismo.

Palavras-chave: Práticas cinegéticas, Interdisciplinaridade, Conservação faunística.

LAS PRÁCTICAS DE CAZA Y LA INFLUENCIA AMBIENTAL: UNA SÍNTESIS GENERAL DESDE UNA PERSPECTIVA ETNOZOOLÓGICA

Resumen - La caza de animales silvestres sigue siendo una práctica recurrente en todo el mundo, motivada por múltiples factores y directamente relacionada con aspectos culturales y ambientales. Debido a la amplia gama de enfoques posibles sobre el tema de la caza, la etnozoología busca entenderlo bajo un enfoque interdisciplinario, considerando los aspectos históricos, éticos, sociales, económicos, culturales y ambientales especies relacionados. Esto justifica su importancia como herramienta de conservación. Por lo tanto, este artículo es parte de una investigación heurística y busca sintetizar las principales consideraciones sobre la caza y su dinamismo.

Palabras clave: Prácticas cinegéticas, Interdisciplinariedad, Conservación faunística. 


\section{INTRODUCTION}

The historical interaction established between humans and animals represents one of the most continuous ways of interaction between humanity and the natural resources (Alves et al. 2009a). This multiplicity of connections that human cultures preserve with animals is frequently approached by an ethnozoological approach, which investigates the cultural knowledge, interpretation and the use of fauna in human societies (Marques 2002).

Despite of being an illegal practice in Brazil (Federal Law No 5.197/ 1967), hunting still pressures several animal species (Alves et al. 2009a, Fernandes-Ferreira 2014) and, along with habitat degradation, it can increase faunal vulnerability (Barbosa and Aguiar 2015).

In spite of this scenario, the ethnozoological studies that focus on hunting practices, their sociocultural and ecological importance, and the environmental services provided by wildlife (García-Flores et al. 2017, FernandesFerreira and Alves 2017, Alves et al. 2007). However, the preponderance of these practices may contribute to trigger serious environmental conflicts related to socioeconomic and cultural-historical aspects (Barbosa and Aguiar 2012).

Before the thematic breadth intrinsic to hunting, it is necessary to discuss it under a comprehensive perspective and that also takes into consideration the varied aspects that parallels with its causes, motivations, effects and implications (Alves and Albuquerque 2017). Therefore, this article derives from a heuristic investigation of national and international academic texts, and aims to summarize into theoretical review, the main considerations regarding hunting practices, in a multidisciplinary approach and from the standpoint of Ethnozoology.

\section{ThE MULTiPLE RELATIONS BETWEEN HUMANS AND ANIMALS}

The historical interaction formed between human beings and animals is largely recognized as relevant in different regions of the world, within the broadest cultural, economic and social contexts (Marques 1995). These interactions can represent not only traditional forms of knowledge and rational usufruct of faunal resources but also mechanisms of animal overexploitation and environmental pressure on their natural populations (Marques 2001).

The many possibilities of combining cultural and environmental factors can lead to the use of the same animal species in a vast array of ways and purposes in distinct societies. In the same scenario, various species can present similar utilities. Generally, these relationships take into consideration the usefulness of the animals, as well as the oral tradition about them, which is transmitted from one generation to another (Thomas 1983, Marques 2002).

At first, one of the most fundamental ways of exploiting the fauna is through hunting and fishing in order to attend human nutrition (Reitz and Wing 2008, Alves 2012, Neufeld and Richmond 2017, Alves and Albuquerque 2017). The types of animals used for this purpose involves the usage of small invertebrate animals and also large vertebrate animals, particularly mammals, birds and reptiles (Redford and Robinson 1987, Robinson and Redford 1991, Klemens and Thorbjarnarson 1995, Nasi et al. 2008), which represent the main source of animal protein in several rural and urban communities around the globe (Peres 2000, Fa et al. 2003, Schenck et al. 2006, Alves et al. 2009b).

Another ample group of relationships between humans and animals concerns aspects related to health. Alves (2012) highlights five important aspects that need to be considered in this context: the fauna acts as the cause and as disseminator of diseases to humans, and vice versa, the animals act as bioindicators or signals of the potential risk of certain diseases, fauna specimens are used in traditional medical treatments by societies worldwide, animals are exploited when bioprospecting for drugs, the fauna is largely utilized in medical investigation.

Since ancient times human beings relate the emergence of some diseases to the presence or influence of certain animals (Ávila-Pires 1989), which, in certain cases is true, since several animals can act as vectors or 
natural reservoirs of diseases (Fong 2017) that directly influence public health, economy and the conservation of biodiversity all around the world (Cleaveland et al. 2001, Friend 2006). It is estimated that, from the emerging infectious diseases, around $75 \%$ have some sort of connection with animals, from that amount, 800 are known zoonotic pathogens (Taylor et al. 2001, Woolhouse and Gowtage-Sequeria 2005, Chomel et al. 2007).

Humans and animals share many diseases (Bell et al. 1988, Krauss 2003) and therefore some species from fauna can be excellent indicators of risk and vulnerability, warning prematurely to the need of interventions in the field of public health (Reif 2011), either by denouncing known pathogens being disseminated in a new location, as well as the direction of their propagation, or indicating fluctuations in their incidence or prevalence over time, besides making possible hypothesis tests specific to their biology and the efficiency of potential mechanisms related to their control (Mc Cluskey 2003). Despite of not being a solidified methodology in disease prevention, the observation of zoological evidences in public health analysis has gained space among disease prevention policies (Scotch et al. 2009, Alves 2012).

Besides being potential disease transmitters and useful bioindicators in public health, many animals are directly utilized for therapeutic purposes since ancient times, with historical records of this type of usage in traditional medical systems in different parts of the world (Stephenson 1832, Moquin-Tandon 1861, Mackinney 1946, Scarpa 1981, Nakanishi 1999, Unnikrishnan 2004, e.g. Alves and Rosa 2005, 2007a, b, 2012).

Asian societies stand out in the usage of fauna and its by-products for the treatment of diseases (Yinfeng et al. 1997, Unnikrishnan 1998), however, Africa and Latin America, in spite of not being much studied, it has been documented an ample usage of the animal biodiversity in zootherapeutic treatments (Alves and Alves 2011, Alves 2012, Barbosa et al. 2018). There are still accounts of this practice in some European countries (Quave et al. 2010, Voultsiadou 2010, Ceriaco 2012).

This widespread use of animals for therapeutic purposes has strengthened in recent years (e.g. Alves and Rosa 2007a, b, Robinson and Zhang 2011), shifting from being mainly a local practice to become one of the main reasons for the illegal wildlife trade (Cleva 2006, IFAW 2011), also representing a major additional pressure to the decline of several animal species populations (Call 2006, Alves et al. 2007). Thus, to consider and comprehend such uses is of the uttermost importance in the context of faunistic conservation (Alves 2012).

Despite its contribution to traditional medicine, fauna is also used as raw material in modern medical science and pharmacology (Sifuna 2012), its potential has been recognized through many studies over the past decades (Fusetani 2000, Chivian 2002, Dossey 2010, Alves and Rosa 2012, Alves and Albuquerque 2012). Since the number of animal species is many times superior to plants, it is assumed that the pharmacological and therapeutic potential of fauna it is still very much overlooked (Trowell 2003, Alves and Albuquerque 2012). Nevertheless, a considerable number of animal-derived ingredients have been tested by the modern pharmaceutical industry (Kunin and Lawton 1996, World Resources Institute 2000, Chivian 2002).

This trend towards the growth of bioprospecting for drugs of animal origin requires conservation strategies to avoid overexploitation, for many target organisms, of known potential, are already vulnerable (Alves 2012, Alves and Albuquerque 2012).

Besides being employed in traditional medicine and in drug manufacturing, animals are largely used in tests and experiments with implications for human health (Bishop and Nolen 2001, Chorilli et al. 2009). An estimated 35 million animals are used every year in research and medical experiments (Alves 2012). This usage, despite of being widespread, generates ethical debates about animal suffering and animal rights that need to be considered and discussed (Singer 1993, Bishop and Nolen 2001, Singer 2004, Tonella et al. 2016).

Another type of interaction between humans and fauna is through the use of pets. The employment of pet animals dates back to the oldest societies that would capture, keep and raise them (Collar et al. 2007, Carrete and Tella 2008), establishing this behavior upon their culture and local tradition (Carvalho 1951, Bueno 2009, Alves et al. 2012, Alves and Albuquerque 2017). Vertebrates are usually more domesticated especially mammals, birds and fish, however, the use of reptiles and amphibious has risen (Fitter 1986, Hoover 1998, Franke and Telecky 2001, 
Jepson and Ladle 2005, Alves et al. 2011). This rising usage of wild animals as pets, however, has been stimulating the illegal wildlife trade, and it has a possible impact on natural populations, which requires to be considered in conservation strategies (Andrews 1990, Broad 2001, Alves et al. 2012).

Some studies clearly correlate the closeness between humans and animals with considerable gains to physical and mental health of patients stricken with different ailments and on people's wellbeing (Fitter 1986, Netting et al. 1987, Jorgenson 1997, Silveira 1998, Brodie and Biley 1999, Serpell 2006, Matuszek 2010). This fact deserves to be taken into consideration by public health policies and as therapeutic alternatives, being careful not be neglected, even when dealing with the use of wild fauna.

Another form of human interaction with fauna concerns the diverse artistic expressions, symbolic, mythological and religious established in every historical period (Yoder 1947, Klingender 1971, Spears et al. 1996, Shepard 1996, Beardsworth and Bryman 2001, Sax 2002, Turner and Freedman 2004, Kalof and Resl 2007, Collar et al. 2007, Senior 2009, Herrmann et al. 2010, Sexton 2011, Garcia 2012, Alves 2012). Alinei (2000), suggests that the first universally known religion, Totemism, included the cult of fauna, this practice is still relevant in religious rites around the world, the animals are considered gods and used as amulets and as sacrificial offerings (Adeola 1992, Léo Neto et al. 2009, Léo Neto and Alves 2010, Alves and Souto 2010, Léo Neto et al. 2011, 2012, Alves 2012), a fact that exerts influence on environmental perception and the use of natural resources to this day (Berkes 2001, Tomalin 2004, Shiu and Stokes 2008, Alves 2012).

Another historical classic way of using animal products is on ornamentation and production of objects with their by-products, such as bones, teeth, horns, feathers, furs, etc., employed as ornaments, clothing or weapons since the most remote societies (Neufeld 1973, Oldfield 2001, Pedersen 2004).

Birds, due to their feathers and plumage, are some of the most explored groups for ornamentation, by traditional populations as well as by modern societies in different contexts (Biebuyck and Van Den Abbeele 1984, Collar et al. 2007, Kothari 2007, Alves 2012). Mammals are also expressively exploited, mainly for their furs and for ivory that can be obtained from some species, the use of ivory dates back to 30.000 years (Kunz 1916, Conard 2003).

Nowadays, besides ivory, furs, feathers and fibers from many species of mammals, reptiles, birds and fish fuel the international trade for the manufacturing of clothing, boots and shoes, bags and other items (Oldfield 2001, Alves 2012, Duda et al. 2017).

Moreover, as the first humans stand out intellectually, they would leave behind nomadism and started dominating and domesticating other species, which represents one of the great milestones in the development of civilization (Thomas 1956, Sulman 1982, Beck and Katcher 1996, Kisling 2001). The domestication of fauna allowed that the first human societies enrich their diets with regular sources of meat, milk and other derivatives (Alves and Souto 2010). Subsequently, some domesticated animals provided news sources of traction such as wagons and riding, or for the traction of plows and coaches (Alves 2012) multiplying human productive capacity and spatial mobility (Ribeiro 1998).

Nowadays, domesticated animals remain essential to human development, providing nutrition, income, transportation, locomotion, company and entertainment (Scanes 2003), however, several wild species are also captured for captive breeding to attend different purposes, which places this theme as relevant to conversation.

\section{The MUltifunCtionality IN HUNTING}

In distinct societies, several functions are closely and inevitably connected to hunting activities. Therefore, hunting does not only consists of chasing, slaughter or capturing wild animals, but, it is also an important part of environmental management, that can influence biodiversity conservation, as well as the success of other human activities, interfering economically and socioculturally in certain regions (Lund and Jensen 2017). 
In many rural areas, hunting essentially models the manners of human subsistence and the natural environment (Adams et al. 2009). Accordingly, Fischer et al. (2012), places hunting practices as a significant share in the totality of activities related to the management wild fauna. To these authors, the multifunctionality of hunting denotes the multiple benefits that hunting and its practices can result to society, serving as food, recreation, income, cultural identity and the desirable ecological results.

In some regions in the European continent, hunting practices are considered as a constituent part of environmental management. In Scotland and Sweden there is moose and deer management in order to maintain the populations of these animals aiming at sport and recreational hunting, along with commercial silviculture (Wennberg Digasper 2008). This type of management also results in variation in the abundance of animal species associated with, such as predators or preys (Blanco-Aguiar et al. 2008, Casas and Viñuela 2010).

In Spain, another example of the ecological functionality of hunting is the management of red-legged partridge populations - bird associated with agricultural areas (García et al. 2008). However, the commercial hunting of these birds demands an intensive management, which denotes the control of predators (legal and illegal ones), provoking tensions between hunting management and conservation of these predators (Villafuerte et al. 1998, Virgós and Travaini 2005).

In Croatia and Slovenia, hunting is the main tool to control the number of brown bears, which reached the "socially acceptable maximum" (Huber et al. 2008a). Similarly, Norway aims to keep the population of lynxes stable through controlled hunting, aiming to reduce conflicts associated with the loss of areas to livestock farming (Linnell et al. 2010). In all these places, hunting has, therefore, a clear role as population control in an ecological perspective.

In the African continent, examples of the ecological functionality of hunting can also be seen. In Ethiopia and Tanzania, hunting is currently employed to control populations that affect the means of human subsistence (Nelson 2007). Nevertheless, in these cases there is a strong economic influence, which highlights another functionality of hunting.

In the southwest of Ethiopia and in the west of Serengeti, in Tanzania, the hunting of smaller animals is conveniently utilized as food by the hunters, however, when the game animal is larger in size, usually its byproducts are commercialized and can generate a significant income (Loibooki et al. 2002, Fischer et al. 2012).

In Europe and in regions of Asia, not only the direct use of animal sub-products generates income, but connected activities, such tourism and recreation generate a significant economic return (Mattsson et al. 2008, Macmillan and Leitch 2008, Caro et al. 2009, Willebrand 2009, Lund and Jensen 2017), a fact that is also consolidated in some regions of Africa that already explore ecotourism (Thirgood et al. 2008).

There are still the social functions of hunting, which relate primarily to the development and conservation of share capital and status - or symbolic capital (Bourdieu 1977, Putnam 2000). As Lund and Jensen (2017) observe, the practice of hunting can be seen as a sign of male bravery and maturity by some human populations in Africa and Asia, while disregarded by others.

In European areas, in turn, hunting can be represented as a cultural perpetuation trait and as an important relation with social status in different classes (Macmillan and Leitch 2008). There are still situations where hunting practices have recently become regular recreational activities (Frković 2002, Huber et al. 2008b).

In general, hunting can possess significant social functions, since it helps to develop symbolic and sociocultural capital, particularly in when it comes to the occurrence and perpetuation of bonds inside social groups. These relations may, in some cases, be transferred to the economic capital (Bourdieu 1977).

In North and Central America, the same multifuncionality of hunting has already been described, with emphasis on studies carried out in Mexico, Nicaragua and Trinidad. The majority of these works, nonetheless, are based in studies about traditional or indigenous populations (León and Montiel 2008, Santos-Fita et al. 2012). In Brazil, despite of hunting being illegal, some studies have also demonstrated these varied nuances of hunting 
activities (Barbosa et al. 2011, Alves et al. 2012, Barbosa and Aguiar 2015). Recently, a thorough study tried to analyze the multiple aspects of hunting in different biomes in the country (Fernandes-Ferreira 2014).

It is worth mentioning that hunting practices are not exclusively related to benefits. Hunting and the corresponding management activities can also result in undesirable outcomes, such as defaunation, overexploitation and the extinction of fauna species. Therefore, besides contributing simultaneously to achieve various goals, these practices also have their cost (Abler 2004, Garrido 2009, Linnell et al. 2010, Lund and Jensen 2017).

In order to better understand whether the multifunctionality of hunting in environments where it occurs has a positive balance or results in serious environmental impacts, it is necessary to identify the most explored cultural target species (Cristancho and Vining 2004), considering their ecological services (Garibaldi and Turner 2004). Only in this way is it possible to understand the typical dynamism of relations between humans and local biodiversity (Sousa 2014).

\section{HuNTING PRACTICES AND ENVIRONMENTAL IMPACTS}

Despite the fact that hunting is an activity directly connected to fauna, its impacts cross over different environmental components, possibly being able to interfere directly with the general balance of ecosystems (Redford 1992). One example of this influence is documented by Wright (2003), stressing that depending on the animal species being hunted and the intensity of its exploitation, there may be alteration in the dynamics of the plant community that ecologically relates with these animals, whilst this same fact could influence species from fauna that are not being hunted, which would tend to occupy vacant niches, resulting in behavioral alteration.

Corroborating the aforementioned work, a complex ecological study carried out in Malaysia suggested that hunting practices affected a considerably larger area in the rainforest of Lambir Hills National Park when compared to deforestation and wood extraction combined (Harrison et al. 2013). This study concluded that the continuity of hunting in the region in the last fifteen years contributed to substantial changes in the spatial structure and in the dynamics of tree populations, culminating with a decline of local vegetation diversity over time.

Besides affecting the plant biodiversity, it is clear that hunting practices considerably affect fauna, having an impact on the size of populations, on age distribution, on sex ratio, on behavior and on the distribution of natural populations (Clausen et al. 2017). It is known that mammals and birds are historically the animal groups most affected by hunting, due to their medium size and population abundance, which yields more protein (Trinca and Ferrari 2006, Martínez 2006).

In an attempt to comprehend if hunting in the Udrungwa Mountains, in Tanzania, affected more intensely the populations of primates than the degradation of their habits, Rovero et al. (2012) monitored populations of five different primates for six years. The results showed that in forest areas with distinct measures of habitat protection there was no significant variation in the population of some primates, whereas the differences in hunting intensity strongly influenced these populations.

Another study performed in Beskydy, between Slovakia and the Czech Republic, showed that hunting acts as a reducer in the availability of food for carnivorous mammals, with particular emphasis on canines and felines (Kutal et al. 2016). This study analyzed the population dynamics of great carnivores between 2003 and 2012 and concluded that variations in hunting practices and their influence on the disponibility of preys in different scenarios resulted in a considerable behavioral disparity among the predator populations studied.

Seeking to comprehend how hunting acted upon a bird migration corridor between Norway and Denmark, Clausen et al. (2017) analyzed the impact of the killing of birds based on 25 years of population monitoring. The authors documented a considerable raise in the ratio of slaughtered individuals in hunting over the last years, which culminated in alterations to age structure of the populations, a fact that can carry a serious influence over the reproduction dynamics of these birds. 
The hunting practices indeed entail environmental impacts that need to be considered in any environmental management plan, whatever the studied area and independent of the hunted species, once that the continuity of these activities interfere in the general balance of the natural ecosystems (Fernandes-Ferreira 2014, Talukdar and Gupta 2017).

\section{HunTING AND ITS ETHICAL AND CONFLICTING ASPECTS}

Hunting is a practice that evokes an intense and immediate moral judgement, which many times is extremely significant when discussing wildlife management. A solidified theoretical framework discuss these moral arguments from a historical perspective (Mackenzie 1987, Steinhart 1989, Adams et al. 2009), normative (Curnutt 1996, List 2004, Kretz 2010) or philosophical (List 1997, Bergman 2005, Vitali 2010), emphasizing specific types of hunting, however, they are incipient studies that base their explorations on empiric data, which are contextualized and analyzed systematically (Fischer et al. 2013).

On the one hand, there are authors that validate hunting practices by presenting opinions and arguments from hunters as part of anthropological analysis, as done by Dahles (1993) in Holland and Marvin (2000) in England. On the other hand, there are researchers that raise consistent arguments opposed to hunting, stating that debates on the subject should not be simplified (Minnis 1996).

Although the moral arguments must be analyzed taking into consideration their historical configurations and the social aspects involved (Setten 2004), the appreciation of different scenarios does not make it impossible the investigation of similarities and patterns of morality through different contexts (Smith 2000). A seeming model of legitimation - or delegitimation - of the use of natural resources, including the animals hunted, tends to highlight four moral arguments: the identity of the user, the kind of practice, the objectivity of this practice and its site of application (Minnis 1996, e.g. Brown 2007a, b).

What it seems to be a trend is the fact that the opinions about the legitimacy of hunting vary between the different types of practice, where the perceptions of motivations and forms of hunting perform an important role in the establishment of these points of view (Heberlein and Willebrand 1998), making it possible to question the morality of the so-called "traditional hunting" and the evaluation of the relevance of these practices within the context of traditional ecological knowledge (Reo and Whyte 2012).

\section{ETHNOZOOLOGY}

Ethnozoology is a subdiscipline of Ethnobiology, which combines elements of social sciences and natural sciences. Thus, scientists and researchers that are dedicated to this field of study, encompass aspects related to zoology, ecology, anthropology, sociology and related areas, crossing the subjective methodology of social sciences and the more objective aspects of biological sciences, seeking to investigate and better understand the complexity of the relations humans develop with the natural environment (Alves and Souto 2015, Alves and Albuquerque 2017).

\section{Historical ASPECTS OF ETHNOZOOLOGY}

Animals and humans are connected in multiple ways, since the most remote cultures from the Old World (Ponting 1995). And these ways of interaction were very well represented by archaeological inscriptions and rock art, which includes hieroglyph and even official documents (Baker 1941, Dodd Jr 1993). 
Despite of this well established relation, the beginnings of Ethnozoology, according to Alves and Souto (2015) bring us to the natural expansionism that started in the sixteenth century, with works from many researchers that were interested in the fauna of the New World and in the knowledge of the natives over the utilization of the fauna. This research field had got so strengthened that, in the nineteenth century, naturalists from the whole world relied upon the collaboration of traditional populations and native communities for the discovery and description of thousands animal species (Moreira 2002).

The lack of ample dissemination and recognition of this collaboration, however, contributed to misconceptions of indigenous people all over the world, excluding an ethnozoological point of view in favor of a classic zoological and detached from traditional knowledge standpoint (Alves and Souto 2015). It is necessary to consider, however, that currently many local populations continue to be essential to the completion of several ecological and zoological works, but, hardly they are mentioned or given the credit (Silvano and Valbo-Jorgensen 2008).

The references made to "Ethnozoology" date back to 1899, in an article about American indigenous people (Mason 1899). Its acknowledgment as a discipline dates back to 1914, when Henderson and Harrington (1914) defined Ethnozoology as the study of cultures and their relationships with the animals in the environment that surrounds them. The term would only primarily be remembered from the 1920s on (Santos-Fita and Costa-Neto 2007), and its definitions would become more refined, such as the one coined by Marques (2002), that considers Ethnozoology as the transdisciplinary study of thoughts and perceptions (beliefs and knowledge), feelings (emotional aspects), and behaviors (attitudes) that mediate the relations between human populations and species of fauna in the ecosystems that surround them.

After the publication of the first studies explicitly focused on Ethnozoology, the progress of the researches in the area is associated with researches of folk taxonomy nature (Chamberlin 1908, e.g. Malkin 1956a, b, 1958, Sturtevant 1964, Berlin et al. 1973). Recently, however, the diversity of the aspects approached in the area is growing considerably, with researches that include zoological perception and classification (Posey 1982, Mourão et al. 2006), myths and beliefs involving the animals (Lewis 1991, Léo Neto et al. 2009, Barbosa and Aguiar 2012), sociobiological aspects of the use of fauna (Posey 1978, Dias et al. 2011, Barbosa and Aguiar 2015), traditional medicine, cosmetic, ritualistic and nutritional aspects including animals (Costa-Neto and Oliveira 2000, Lev 2003, Alves and Pereira Filho 2007, Barboza et al. 2007, Alves et al. 2011, Rosa et al. 2011), domestication and management of faunistic resources (Haudricourt 1977, Digard 1992), the cognitive processes related to the management of fauna and the conservation of biodiversity (Fleck and Harder 2000, Alves and Nishida 2002) and hunting and its impacts on animal populations (Balée 1985, Quijano Hernandez and Calme 2002, Souto 2007, e.g. Alves et al. 2009a, b, c, 2012, Barbosa et al. 2010, 2011, Bezerra et al. 2012, Souza and Alves 2014), tending towards growth and expansion of the researches done in Brazil.

\section{THE MULTIDISCIPLINARY IMPORTANCE OF ETHNOZOOLOGY TO CONSERVATION}

A number of studies currently demonstrate that human populations possess vast knowledge about the natural resources that are directly used, especially the one about the fauna (Mourão and Nordi 2002, 2006, Mourão et al. 2006, Souto et al. 2011, Alves and Rosa 2012, Alves et al. 2013). These types of knowledge have attracted attention from the scientific community around the world, once they can complement scientific information and provide significantly relevant data on the assessment of environmental impacts, the management of natural resources and sustainability (Posey 1984, Alves and Souto 2015).

Just as academic knowledge, the traditional zoological knowledge derives from systematic observation of nature, although it is interpreted in a unique cultural context, resulting in data on local natural phenomena, as well as knowledge about the relationships established with the resources originated from the ecosystems (Nishida et al. 2006). Nonetheless, this vast source of knowledge has being historically overlooked by the scientific community 
(Alves and Nishida 2002) and just recently has being considered and recognized by scientists from different areas of knowledge (Tidemann and Gosler 2010, Alves and Souto 2015).

It is worth mentioning that individuals that possess a considerable zoological knowledge are the ones that seize the faunistic resources more directly - such as hunters, fisherman, and gatherers, thus, the success of their practices is directly linked to the quality and the reliability of their biological knowledge (Marques 1995, Begossi et al. 2008, Nordi et al. 2009, Capistrano and Lopes 2012). As a result, these individuals present a vast range of information susceptible to complement with great quality academic studies on Ethnozoology, population biology, ecological interactions, weather patterns, environmental assessment and management, conservation status and adaptive management of faunistic resources (Berkes 1999, Alves and Nishida 2002, Rosa et al. 2005).

This array of aspects for the applicability of ethnozoological knowledge, reinforces its role as an important tool that has contributed to environmental studies, along with the analysis of economic and social aspects inherent in the use and conservation of the biodiversity of fauna, enabling environmental management and species conservation planning, considering the socioeconomic circumstances of the individuals concerned (Alves and Nishida 2003, Rocha-Mendes et al. 2005, Alves and Souto 2015).

The ethnobiological studies - with emphasis being placed on the ethnozoological ones - are directly associated with resource management and conservation biology, have much to add to these disciplines, since all conservation strategies need to contemplate the sociocultural and economic aspects concerned (Begossi 2006, Lopes et al. 2010, Alves and Souto 2015).

\section{FinAL CONSIDERATIONS}

It is evident that the multiplicity of approaches relating to hunting was historically and globally constructed and disseminated by humanity, but, it also occurs in local contexts that legitimate or not, its continuity, minimizing or amplifying its impacts.

Despite of its cultural and nutritional importance, hunting is still poorly studied, figuring as one of the great threats to animal biodiversity, therefore, it is necessary more studies that seek to understand its dynamics and its role on the support of human societies, along with its influence regarding conservation.

Ethnozoology comes out as one of the most effective tools to the understanding of the relationships established between humans and animals, aiming for sustainability. This efficiency is due to the possibility of an interdisciplinary alliance between methodologies from different sciences, in an attempt to understand a complex thematic context that cannot be really comprehended through a disciplinary approach.

\section{ACKNOWLEDgMenTs}

The authors would like to thank Universidade Federal de Campina Grande (UFCG)/ Coordenação de Aperfeiçoamento de Pessoal de Nível Superior (CAPES) for the PhD fellowship conceded to the first author.

\section{REFERENCES}

Abler D. 2004. Multifunctionality, Agricultural Policy, and Environmental Policy. Agricultural and Resource Economics Review, 33 (1): 8-17. 
Adams WM, Dickson B, Dublin HT, Hutton J. 2009. Conservation, Livelihoods and Recreational Hunting: Issues and Strategies. In: Dickson B. et al. (eds), Recreational Hunting, Conservation and Rural Livelihoods, London: WileyBlackwell - England, p. 363-372.

Adeola MO. 1992. Importance of wild animals and their parts in the culture, religious festivals, and traditional medicine, of Nigeria. Environmental Conservation, 19 (2): 125-134.

Alinei M. 2000. A stratigraphic and structural approach to the study of magico-religious motivations. Južnoslovenski filolog, 56 (1): 75-92.

Alves RRN, Albuquerque UP. 2012. Ethnobiology and conservation: Why do we need a new journal? Ethnobiology and Conservation, 1 (1): 1-3.

Alves RRN, Albuquerque UP. 2017. Ethnozoology: Animals in Our Lives. 1ed, London: Academic Press - Elsevier, 552p.

Alves RRN, Alves HN. 2011. The faunal drugstore: Animal-based remedies used in traditional medicines in Latin America. Journal of Ethnobiology and Ethnomedicine, 7 (9): 1-43.

Alves RRN, Barbosa JAA, Santos SLDX, Souto WMS, Barboza RRD. 2011. Animal-based remedies as complementary medicines in the semi-arid region of northeastern Brazil. Evidence-Based Complement Altern Med. 11 (1): 1-15.

Alves RRN, Gonçalves MBR, Vieira WLS. 2012. Caça, uso e conservação de vertebrados no semiárido Brasileiro. Tropical Conservation Science, 5 (3): 394-416.

Alves RRN, Leite RC, Souto WMS, Bezerra DMM, Lourdes-Ribeiro A. 2013. Ethno-ornithology and conservation of wild birds in the semi-arid Caatinga of northeastern Brazil. Journal of Ethnobiology and Ethnomedicine, 9 (14): 1-12.

Alves RRN, Léo Neto NA, Santana GG, Vieira WLS, Almeida WO. 2009c. Reptiles used for medicinal and magic religious purposes in Brazil. Applied Herpetology, 6 (1): 257-274.

Alves RRN, Mendonça LET, Confessor MVA, Vieira WLS, Lopes LCS. 2009a. Hunting strategies used in the semi-arid region of northeastern Brazil. Journal of Ethnobiology and Ethnomedicine, 5 (12): 1-16.

Alves RRN, Nishida AK. 2002. A ecdise do caranguejo-uçá, Ucides cordatus L. (Decapoda, Brachyura) na visão dos caranguejeiros. Interciencia, 27 (3): 110-117.

Alves RRN, Nishida AK. 2003. Aspectos socioeconômicos e percepção ambiental dos catadores de caranguejo-uçá Ucides cordatus cordatus (L. 1763) (Decapoda, Brachyura) do estuário do Rio Mamanguape, Nordeste do Brasil. Interciencia, 28 (1): 36-43.

Alves RRN, Oliveira MGG, Barboza RRD, Singh R, Lopez LCS. 2009b. Medicinal Animals as therapeutic alternative in a semi-arid region of Northeastern Brazil. Forsch Komplementmed/Research in Complementary Medicine, 16 (5): $305-$ 312.

Alves RRN, Pereira-Filho GA. 2007. Commercialization and use of snakes in North and Northeastern Brazil: implications for conservation and management. Biodiversity and Conservation, 16 (4): 969-985.

Alves RRN, Rosa IL, Santana GG. 2007. The role of animal-derived remedies as complementary medicine in Brazil. BioScience - Berkeley, 57 (11): 949-955. 
Alves RRN, Rosa IL. 2005. Why study the use of animal products in traditional medicines? Journal of Ethnobiology and Ethnomedicine, 1 (1): 1-5.

Alves RRN, Rosa IL. 2012. Animals in Traditional Folk Medicine: Implications for Conservation. New York: SpringerVerlag, 492p.

Alves RRN, Rosa IL. 2007a. Zootherapeutic practices among fishing communities in North and Northeast Brazil: A comparison. Journal of Ethnopharmacology, 111 (1): 82-103.

Alves RRN, Rosa IL. 2007b. Zootherapy goes to tawn: The use of animal-based remedies in urban areas of NE and N Brazil. Journal of Ethnopharmacology, 113 (3): 541-555.

Alves RRN, Souto WMS. 2010. Etnozoologia: conceitos, considerações históricas e importância. In: Alves RRN et al. (Eds.). A Etnozoologia no Brasil: Importância, Status atual e Perspectivas. Recife: NUPEEA - Brazil, pp.19-40.

Alves RRN, Souto WMS. 2015. Ethnozoology: A Brief Introduction. Ethnobiology and Conservation, 4 (1): 1-13.

Alves RRN. 2012. Relationships between fauna and people and the role of ethnozoology in animal conservation. Ethnobiology and Conservation, 1 (1): 1-69.

Andrews C. 1990. The ornamental fish trade and fish conservation. Journal of Fish Biology, 37 (Supplement A): 53-59.

Ávila-Pires FD. 1989. Zoonoses: hospedeiros e reservatórios. Cadernos de Saúde Pública, 5 (1): 82-97.

Baker FC. 1941. A study of ethnozoology of the prehistoric Indians of Illinois. Transactions of the American Philosophical Society, 32 (1): 51-77.

Balée W. 1985. Ka’apor ritual hunting. Human Ecology, 13 (4): 485-510.

Barbosa JAA, Aguiar JO, Alves RRN. 2018. Medicinal use of animals by hunters in North eastern Brazil. Indian Journal of Traditional Knowledge, 17 (3): 1-14.

Barbosa JAA, Aguiar JO. 2012. Utilização místico-tradicional da fauna no semiárido paraibano. Revista Polêm!ca, 11 (4): 642-649.

Barbosa JAA, Aguiar JO. 2015. Conhecimentos e usos da fauna por caçadores no semiárido brasileiro: um estudo de caso no estado da Paraíba, Nordeste do Brasil. Biotemas, 28 (2): 137-148.

Barbosa JAA, Nobrega VA, Alves RRN. 2010. Aspectos da Caça e Comércio ilegal da Avifauna Silvestre por Populações Tradicionais do Semi-árido Paraibano. Revista de Biologia e Ciências da Terra, 10 (2): 39-49.

Barbosa JAA, Nobrega VA, Alves RRN. 2011. Hunting practices in the semiarid region of Brazil. Indian Journal of Traditional Knowledge, 10 (3): 486-490.

Barboza RRD, Souto WMS, Mourão JS. 2007. The use of zootherapeutics in folk veterinary medicine in the district of Cubati, Paraíba State, Brazil. Journal of Ethnobiology and Ethnomedicine, 3 (32): 01-14.

Beardsworth A, Bryman A. 2001. The wild animal in late modernity: The case of the Disneyization of zoos. Tourist Studies, 1 (1): 83-104. 
Beck AM, Katcher AH. 1996. Between pets and people: The importance of animal companionship. 1 ed. West Lafayette: Purdue Univ Pr - USA.

Begossi A, Clauzet M, Figueiredo JL, Guarano L, Lima R, Lopes PFM, Souza MR, Silva AL, Silvano RAM. 2008. Are biological species and high-ranking categories real? Fish folk taxonomy in the Atlantic Forest and the Amazon (Brazil). Current Anthropology, 49 (2): 291-302.

Begossi A. 2006. Temporal stability in fishing spots: conservation and co-management in Brazilian artisanal coastal fisheries. Ecology and Society, 11 (1): 5.

Bell JC, Palmer SR, Payne JM. 1988. The zoonoses (infections transmitted from animals to man). 1 ed. Londres: Arnold.

Bergman C. 2005. Obits for a fallen hunter: reading the decline - and death? - of hunting in America. American Literary History, 17 (1): 818-830.

Berkes F. 1999. Sacred Ecology: Traditional ecological knowledge and resource management. 1 ed. Philadelphia, USA: Taylor e Francis, 236 p.

Berkes F. 2001. Religious traditions and biodiversity. Encyclopedia of Biodiversity, 5 (1): 109-120.

Berlin B, Breedlove DE, Raven PH. 1973. General Principles of Classification and Nomenclature in Folk Biology. American Anthropologist, 75 (1): 214-242.

Bezerra DMM, Araujo HFP, Alves RRN. 2012. Wild birds as source of food in the semi-arid region of Rio Grande do Norte State, Brazil. Sitientibus Série Ciências Biológicas, 11 (2): 177-183.

Biebuyck DP, Van Den Abbeele N. 1984. The power of headdresses: a cross-cultural study of forms and functions. Brussels: Leopold III Foundation for Exploration \& Nature Conservation.

Bishop LJ, Nolen AL. 2001. Animals in research and education: ethical issues. Kennedy Institute of Ethics Journal, 11 (1): 91-113.

Blanco-Aguiar JA, González-Jara P, Ferrero ME, Sánchez-Barbudo E, Virgós R, Villafuerte R, Dávila JA. 2008. Assessment of game restocking contributions to anthropogenic hybridization: the case of the Iberian red-legged partridge. Animal Conservation 11 (1): 535-545.

Bourdieu P. 1977. Outline of a theory of practice. Cambridge: Cambridge University Press, 248p.

Broad S. 2001. The nature and extent of legal and illegal trade in wildlife. Hughes Hall, International and Africa Resources Trust. Cambridge: TRAFFIC.

Brodie SJ, Biley FC. 1999. An exploration of the potential benefits of pet-facilitated therapy. Journal of Clinical Nursing, 8 (4): 329-337.

Brown KM. 2007a. Reconciling moral and legal collective entitlement: implications for community-based land reform. Land Use Policy, 24 (4): 633-643.

Brown KM. 2007b. Understanding the materialities and moralities of property: reworking collective claims to land. Transactions of the Institute of British Geographers, 32 (4): 507-522. 
Bueno FGC. 2009. Homem que não ladra, cão que não morde: A Comunicação Interespécies marcando a Cultura pós-moderna. 110 f. Dissertação de Mestrado. Sorocaba: Programa de Pós-Graduação Mestrado em Comunicação e Cultura, Universidade de Sorocaba.

Call E. 2006. Mending the Web of Life: Chinese Medicine and Species Conservation. 1 ed. Massachusetts: International Fund for Animal Welfare.

Capistrano JF, Lopes PFML. 2012. Crab gatherers perceive concrete changes in the life history traits of Ucides cordatus (Linnaeus, 1763), but overestimate their past and current catches. Ethnobiology and Conservation, 1 (1): 1-21.

Caro JD, Sunyer C, Viñuela J. 2009. Contribución del Parque Nacional de Cabañeros al desarrollo rural del entorno. In: Sunyer C. (Ed.) Eco-emprendedores: Retos para la puesta en valor de los espacios protegidos. Madrid: TERRA centro para la política ambiental, p. 23-30.

Carrete M, Tella JL. 2008. Wild-bird trade and exotic invasions: a new link of conservation concern? Frontiers in Ecology and the Environment, 6 (4): 207-211.

Carvalho JCM. 1951. Relações entre os índios do Alto Xingu e a fauna regional. Manaus: Publicações avulsas do Museu Nacional. 32 p.

Casas F, Viñuela J. 2010. Agricultural practices or game management: which is the key to improve red-legged partridge nesting success in agricultural landscapes? Environmental Conservation, 37 (2): 177-186.

Ceriaco LMP. 2012. Human attitudes towards herpetofauna: The influence of folklore and negative values on the conservation of amphibians and reptiles in Portugal. Journal of Ethnobiology and Ethnomedicine, 8 (1): 1-8.

Chamberlin RV. 1908. Animal Names and Anatomical Terms of the Goshute Indians. Proceedings of the Academy of Natural Sciences of Philadelphia, 60 (1): 74-103.

Chivian E. 2002. Biodiversity: Its Importance to Human Health. Harvard Medical School Cambridge, USA: Center for Health and the Global Environment.

Chomel BB, Belotto A, Meslin FX. 2007. Wildlife, exotic pets, and emerging zoonoses. Emerging Infectious Diseases, 13 (1): 6-11.

Chorilli M, Michelin DC, Salgado HRN. 2009. Animais de laboratório: o camundongo. Revista de Ciências Farmacêuticas Básica e Aplicada, 28 (1): 11-23.

Clausen KK, Christensen TK, Gundersen OM, Madsen J. 2017. Impact of hunting along the migration corridor of pinkfooted geese Anser brachyrhynchus - Implications for sustainable harvest management. Journal of Applied Ecology, 54 (1): 1563-1570.

Cleaveland S, Laurenson MK, Taylor LH. 2001. Diseases of humans and their domestic mammals: pathogen characteristics, host range and the risk of emergence. Philosophical Transactions of the Royal Society of London. Series B: Biological Sciences, 356 (1411): 991-999.

Cleva SUS. 2006. Conservation laws and treaties: support for the web. In: Call E. (ed). Mending the web of life: Chinese Medicine \& Species Conservation. 1 ed. Signature Book Printing, Inc., Beijing - China, pp. 199-214. 
Collar NJ, Long AJ, Jaime PRG. 2007. Birds and People: Bonds in a Timeless Journey. 1 ed. Cambridge: BirdLife International - UK, 360p.

Conard NJ. 2003. Palaeolithic ivory sculptures from southwestern Germany and the origins of figurative art. Nature, 426 (6968): 830-837.

Costa-Neto EM, Oliveira MVM. 2000. Cockroach is Good for Asthma: Zootherapeutic Practices in Northeastern Brazil. Human Ecology Review, 7 (2): 41-51.

Cristancho S, Vining J. (2004). Culturally Defined Keystone Species. Research in Human Ecology, 11 (2): 153-164.

Curnutt J. 1996. How to argue for and against sport hunting. Journal of Social Philosophy, 27 (2): 65-89.

Dahles H. 1993. Game killing and killing games: an anthropologist looking at hunting in a modern society. Society and Animals, 1 (2): 169-184.

Dias TLP, Leo-Neto NA, Alves RRN. 2011. Molluscs in the marine curio and souvenir trade in NE Brazil: species composition and implications for their conservation and management. Biodiversity and Conservation, 20 (11): 2393-2405.

Digard JP. 1992. Un aspect méconnu de l'histoire de l'Amérique: la domestication des animaux. L'Homme, 32 (2): 253-270.

Dodd Jr CK. 1993. Strategies for snake conservation - Ecology and Behavior. New York: McGraw-Hill, Inc., pp. 363393.

Dossey AT. 2010. Insects and their chemical weaponry: New potential for drug discovery. Natural product reports, 27 (12): 1737-1757.

Duda R, Gallois S, Reyes-Garcia V. 2017. Hunting techniques, wildlife offtake and market integration. A perspective from individual variations among The Baka (Cameroon). African Study Monographs, 38 (2): 97-118.

Fa, JE, Currie D, Meeuwig J. 2003. Bushmeat and food security in the Congo Basin: linkages between wildlife and people's future. Environmental Conservation, 30 (1): 71-78.

Fernandes-Ferreira H, Alves RRN. 2017. The researches on the hunting in Brazil: a brief overview. Ethnobiology and Conservation, 6 (6): 1-6.

Fernandes-Ferreira H. 2014. A caça no Brasil - Panorama histórico e atual. 466f. PhD Zoology Thesis. João Pessoa: Universidade Federal da Paraíba.

Fischer A, Kerezi V, Arroyod B, Mateos-Delibesd M, Tadieb D, Lowassae A, Krangef O, Skogenf K. 2013. (De) legitimising hunting - Discourses over the morality of hunting in Europe and eastern Africa. Land Use Policy, 32 (1): 261-270.

Fischer A, Sandström C, Delibes-Mateos M, Arroyo B, Tadie D, Randall D, Hailu F, Lowassa A, Msuha M, Kerezi V, Reljić S, Linnell J, Skrbinšek AM. 2012. On the multifunctionality of hunting - an institutional analysis of eight cases from Europe and Africa. Journal of Environmental Planning and Management, 56 (4): 531-552.

Fitter RSR. 1986. Wildlife for man: how and why we should conserve our species. Londres: Collins, 223p.

Fleck DW, Harder JD. 2000. Matses Indians rainforest habitat classifi cation and mammalian diversity in Amazonian Peru. Journal of Ethnobiology, 20: 1-36. 
Fong IW. 2017. Emerging Zoonoses, Emerging Infectious Diseases of the 21st Century. Springer International Publishing, New York - USA.

Franke J, Telecky TM. 2001. Reptiles as pets: an examination of the trade in live reptiles in the United States. Washington DC: Humane Society of the United States.

Friend M. 2006. Disease emergence and resurgence: the wildlife-human connection. US Department of the Interior, US Geological Survey, Report, Madison - USA, 400p.

Frković A. 2002. Brown bear in Primorsko-goranska county. Rijeka: Department for Economic Development in Primorsko-goranska county.

Fusetani N. 2000. Drugs from the Sea. 1 ed. 158 f. Karger Medical and Scientific Publishers.

Garcia G. 2012. A fauna brasileira escondida na Catedral da Sé. In: http://www.saopauloantiga.com.br/a-faunabrasileira-na-catedral-da-se/.Access: 13 December 2017.

García J, Arroyo B, Viñuela J. 2008. Definición y caracterización de las zonas agrarias de alto valor natural (HNV) en España. Ministerio de Medio Ambiente (MARM). In: http://www.mapama.gob.es/es/biodiversidad/ publicaciones/09047122801632e4_tcm30-197181.pdf Access: 03 January 2018.

García-Flores A, Mojica-Pedraza S, Barreto-Sánchez SD, Monroy-Ortiz C, Monroy-Martínez R. 2017. Ethnozoological Study of Native Birds and Mammals Associated to Fruit Orchards of Zacualpan de Amilpas, Morelos, México. Trop J Environ Sc, 51(2): 110-132.

Garibaldi A, Turner N. (2004). Cultural keystone species: implications for ecological conservation and restoration. Ecology and Society, 9 (3): 1-18.

Garrido EM. 2009. Territorial view of the Spanish cinegetic boom, 1970-1989. Boletín de la Asociación de Geógrafos Españoles, 51 (1): 325-351.

Harrison RD, Tan S, Plotkin JB, Slik F, Detto M, Brenes T, Itoh A, Davies SJ. 2013. Consequences of defaunation for a tropical tree community. Ecology letters, 16 (5): 687-694.

Haudricourt AG. 1977. Note d'ethnozoologie. Le rôle des excrétats dans la domestication. L'Homme, 17 (3): 125-126.

Heberlein TA, Willebrand H. 1998. Attitudes toward across time and continents: The United States and Sweden. Gibier Faune Sauvage - Game Wildlife, 15 (1): 1071-1080.

Henderson J, Harrington JP. 1914. Ethnozoology of the Tewa Indians. Washington, D.C.: Government Printing Office. 100p.

Herrmann T, Costina MI, Costina AM. 2010. Roost sites and communal behavior of Andean condors in Chile. Geographical Review, 100 (2): 246-262.

Hoover C. 1998. The US role in the international live reptile trade: Amazon tree boas to Zululand dwarf chameleons. TRAFFIC, North America. 
Huber D, Jakšić Z, Frković A, Štahan Z, Kusak J, Majnarić D, Grubešić M, Kulić B, Sindičić M, Skrbinšek A, Lay V, Ljuština M, Zec D, Laginja R, Francetić I. 2008b. Brown bear management plan for the Republic of Croatia. In: http://www. mrrsvg.hr/UserDocsImages/Plan\%20gospodarenja\%20smedim\%20medvjedima\%20eng.pdf. Access: 07 January 2018.

Huber D, Kusak J, Majić-Skrbinšek A, Majnarić D, Sindičić M. 2008a. A multidimensional approach to managing the European brown bear in Croatia. Ursus, 19 (1): 22-32.

IFAW - International Fund for Animal Welfare. 2011. Traditional Medicine. In: www.ifaw.org/sites/default/files/Q\&A\%20 Traditional\%20medicine.pdf. Access: 03 December 2017.

Jepson P, Ladle RJ. 2005. Bird-keeping in Indonesia: conservation impacts and the potential for substitution-based conservation responses. Oryx, 39 (4): 442-448.

Jorgenson J. 1997. Therapeutic use of companion animals in health care. Journal of Nursing Scholarship, 29 (3): $249-254$.

Kalof L, Resl B. 2007. A Cultural History of Animals. Berg: Germany. 1536p.

Kisling VN. 2001. Ancient collections and menageries. In: Kisling VN. (ed). Zoo and aquarium history: ancient animal collections to zoological gardens. 1 ed. London: CRC Press, pp. 1-47.

Klemens MW, Thorbjarnarson JB. 1995. Reptiles as a food resource. Biodiversity and Conservation, 4 (3): 281-298.

Klingender F. 1971. Animals in Art and Thought to the End of the Middle Ages. 1 ed. Routledge, Cambridge - UK, $581 \mathrm{p}$.

Kothari A. 2007. Birds in our lives. 1 ed. U.S. Dept. of Interior: Universities Press. 561p.

Krauss H. 2003. Zoonoses: infectious diseases transmissible from animals to humans. 1 ed. Amer Society for Microbiology Press. 456p.

Kretz L. 2010. A shot in the dark - the dubious prospects of environmental hunting. In: Kowalsky N. (Ed.). Hunting Philosophy for Everyone: In Search of the Wild Life. Wiley-Blackwell, Chichester, Boston - USA, pp. 33-44.

Kunin WE, Lawton JH. 1996. Does biodiversity matter? Evaluating the case for conserving species. In: Gaston KJ. (ed). Biodiversity: a biology of numbers and differences. 1 ed. Oxford: Blackwell Science, pp. 283-308.

Kunz GF. 1916. Ivory and the Elephant in Art. 1 ed. New York: Doubleday, Page and Co. 698p.

Kutal M, Váňa M, Suchomel J, Chapron G, López-Bao JV. 2016. Trans-Boundary Edge Effects in the Western Carpathians: The Influence of Hunting on Large Carnivore Occupancy. PLOS ONE, doi:10.1371/journal.pone.0168292.

León P, Montiel S. 2008. Wild Meat Use and Traditional Hunting Practices in a Rural Mayan Community of the Yucatan Peninsula, Mexico. Hum Ecol, 36 (2): 249-257.

Léo-Neto NA, Alves RRN. 2010. A Natureza sagrada do Candomblé: análise da construção mística acerca da Natureza em terreiros de candomblé no Nordeste de Brasil. Interciencia, 35 (8): 568-574.

Léo-Neto NA, Brooks SE, Alves RRN. 2009. From Eshu to Obatala: animals used in sacrificial rituals at Candomble "terreiros" in Brazil. Journal of Ethnobiology and Ethnomedicine, 5 (1): 1-23. 
Léo-Neto NA, Mourão JS, Alves RRN. 2011. "It all begins with the head”: initiation rituals and the symbolic conceptions of animals in Candomblé. Journal of Ethnobiology, 31 (2): 244-261.

Léo-Neto NA, Voeks RA, Dias TLP, Alves RRN. 2012. Mollusks of Candomble: symbolic and ritualistic importance. Journal of Ethnobiology and Ethnomedicine, 8 (1): 1-10.

Lev E. 2003. Traditional healing with animals (zootherapy): medieval to present-day Levantine practice. Journal of Ethnopharmacology, 85 (1): 107-118.

Lewis IM. 1991. The spider and the pangolin. Man, 26 (3): 513-525.

Linnell J, Broseth H, Odden J, Nilsen EB. 2010. Sustainably Harvesting a Large Carnivore? Development of Eurasian Lynx Populations in Norway During 160 Years of Shifting Policy. Environmental Management, 45 (5): 1142-1154.

List CJ. 1997. Is hunting a right thing? Environmental Ethics, 19 (4): 405-416.

List CJ. 2004. On the moral distinctiveness of sport hunting. Environmental Ethics, 26 (2): 155-169.

Loibooki M, Hofer H, Campbell KLI, East ML. 2002. Bushmeat hunting by communities adjacent to the Serengeti National Park, Tanzania: the importance of livestock ownership and alternative sources of protein and income. Environmental Conservation, 29 (3): 392-398.

Lopes PFM, Silvano R, Begossi A. 2010. Da Biologia a Etnobiologia - Taxonomia e etnotaxomia, ecologia e etnoecologia. In: In: Alves RRN, Souto WMS, Mourão JS. (Eds.). A Etnozoologia no Brasil: Importância, Status atual e Perspectivas. Recife: NUPEEA, pp. 67-94.

Lund JF, Jensen FS. 2017. Is recreational hunting important for landscape multi-functionality? Evidence from Denmark. Land Use Policy, 61 (1): 389-397.

Mackenzie JM. 1987. Chivalry, social Darwinism and ritualized killing: the hunting ethos in Central Africa up to 1914. In: Anderson D, Grove R. (Eds.), Conservation in Africa: People, Policies and Practice. Cambridge University Press, Cambridge, pp. 41-61.

Mackinney LC. 1946. Animal substances in materia medica. Journal of the history of medicine and allied sciences, 1 (1): $149-170$.

Macmillan DC, Leitch K. 2008. Conservation with a Gun: Understanding landowner attitudes to deer hunting in the Scottish highlands. Human Ecology, 36 (4): 473-484.

Malkin B. 1956b. Sumu ethnozoology: Herpetological knowledge. Davidson Journal of Anthropology, 2 (1): 165-180.

Malkin B. 1958. Cora ethnozoology, herpetological knowledge, a bioecological and cross cultural approach. Anthropological Quarterly, 31 (3): 73-90.

Malkin B. 1959a. Seri ethnozoology: A preliminary report. Davidson Journal of Anthropology, 2 (1): 73-83.

Marques JGW. 1995. Pescando pescadores: etnoecologia abrangente no baixo São Francisco alagoano. São Paulo: NUPAUB/USP, 285p. 
Marques JGW. 2001. Pescando pescadores: Ciência e Etnociência em uma Perspectiva Ecológica. 2 ed. São Paulo: NUPAUB/USP, 258p.

Marques JGW. 2002. O olhar (des)multiplicado. O papel do interdisciplinar e do qualitativo na pesquisa etnobiológica e etnoecológica. In: Amorozo MCM et al. (eds.). Métodos de coleta e análise de dados em etnobiologia, etnoecologia e disciplinas correlatas. Rio Claro: UNESP/CNPq, p.31-46.

Martinez PH. 2006. História Ambiental no Brasil: pesquisa e ensino. São Paulo: Cortez. 120p.

Marvin G. 2000. The problem of foxes - legitimate and illegitimate killing in the English countryside. In: Knight J. (Ed.). Natural Enemies - Peoplewildlife Conflicts in Anthropological Perspective. London: Routledge, pp. 189-211.

Mason OT. 1889. Aboriginal American Zoötechny. Aboriginal American Zoötechny, 1 (1): 45-81.

Mattsson L, Boman M, Ericsson G. 2008. Jakten i Sverige: ekonomiska värden och attityder jaktåret 2005/06 - Adaptiv förvaltning av vilt och fisk. Umeå: Swedish University of Agricultural Sciences. 40p.

Matuszek S. 2010. Animal-facilitated therapy in various patient populations: systematic literature review. Holistic Nursing Practice, 24 (4): 187-203.

Mc Cluskey BJ. 2003. Use of sentinel herds in monitoring and surveillance systems Salman. Animal disease surveillance and survey systems: methods applications Iowa. 1 ed. Iowa State Press, pp. 119-133.

Minnis DL. 1996. The opposition to hunting: a typology of beliefs. Anais da Transactions of the North American Wildlife and Natural Resources Conference, 62 (1): 346-360.

Moquin-Tandon A. 1861. Elements of medical zoology. 1 ed. Baillière, 446p.

Moreira IC. 2002. O escravo do naturalista - O papel do conhecimento nativo nas viagens científicas do século 19. Ciência Hoje, 31 (184): 40-48.

Mourão JS, Araujo HFP, Almeida FS. 2006. Ethnotaxonomy of mastofauna as practised by hunters of the municipality of Paulista, state of Paraíba-Brazil. Journal of Ethnobiology and Ethnomedicine, 2 (19): 7.

Mourão JS, Nordi N. 2002. Comparações entre as taxonomias Folk e Científica para peixes do estuário do Rio Mamanguape, Paraíba-Brasil. Interciencia, 27 (12): 664-668.

Mourão JS, Nordi N. 2006. Pescadores, Peixes, Espaço e Tempo: Uma Abordagem Etnoecológica. Interciencia. 31 (5): 358-363.

Nakanishi K. 1999. An historical perspective of natural products chemistry. In: Ushio S. (ed). Comprehensive Natural Products Chemistry. 1 ed. Amsterdam: Elsevier Science B.V., pp. 23-40.

Nasi R, Brown D, Wilkie D, Bennett E, Tutin C, Van Tol G, Christophersen T. 2008. Conservation and use of wildlifebased resources: the bushmeat crisis. Montreal: Secretariat of the Convention on Biological Diversity, Bogor: Center for International Forestry Research (CIFOR), 50p.

Nelson F. 2007. Emergent or illusory? Community wildlife management in Tanzania. IIED Paper 146, Nottingham: Russell Press, 38p. 
Netting FE, Wilson CC, New JC. 1987. The human-animal bond: Implications for practice. Social Work, 32 (1): 60-64.

Neufeld E. 1973. Fabrication of Objects from Fish and Sea Animals in Ancient Israel. Journal of the Ancient Near Eastern Society of Columbia University, 5 (1): 314-315.

Neufeld HT, Richmond CAM. 2017. Impacts of Place and Social Spaces on Traditional Food Systems in Southwestern Ontario. International Journal of Indigenous Health, 12 (1): 93-115. doi:10.18357/ijih112201716903

Nishida AK, Nordi N, Alves RRN. 2006. Molluscs production associated to lunar-tide cycle: a case study in Paraíba State under ethnoecology viewpoint. Journal of Ethnobiology and Ethnomedicine, 2 (28): 1-6.

Nordi N, Nishida AK, Alves RRN. 2009. Effectiveness of Two Gathering Techniques for Ucides cordatus in Northeast Brazil: Implications for the Sustainability of Mangrove Ecosystems. Human Ecology, 37 (1): 121-127.

Oldfield S. 2001. The trade in wildlife: regulation for conservation. 1 ed. Londres: Earthscan Publications Ltd London, 232p.

Pedersen MC. 2004. Gem and Ornamental Materials of Organic Origin. 1 ed. Amsterdam: Elsevier ButterworthHeinemann, 282p.

Peres CA. 2000. Effects of subsistence hunting on vertebrate community structure in Amazonian forests. Conservation Biology, 14 (1): 240-253.

Ponting C. Uma história verde do mundo. 1 ed. Rio de Janeiro: Civilização Brasileira, 1995, 646p.

Posey DA. 1978. Ethnoentomological Survey of Amerind Groups in Lowland Latin America. The Florida Entomologist, 61 (4): 225-229.

Posey DA. 1982. The Importance of Bees to Kayapo Indians of the Brazilian Amazon. The Florida Entomologist, 65:452-458.

Posey DA. 1984. Ethnoecology as applied anthropology in Amazonian development. Hum. Organ., 43 (2): 95-107.

Putnam RD. 2000. Bowling alone: the collapse and revival of American community. New York: Simon \& Schuster, 135p.

Quave CL, Lohani U, Verde A, Fajardo J, Rivera D, Obón C, Valdes A, Pieroni A. 2010. A comparative assessment of zootherapeutic remedies from selected areas in Albania, Italy, Spain and Nepal. Journal of Ethnobiology, 30 (1): 92-125.

Quijano-Hernández E, Calmé S. 2002. Patrones de cacería y conservación de la fauna silvestre en una comunidad maya de Quintana Roo, México. Etnobiología, 2 (1): 1-18.

Redford KH, Robinson JG. 1987. The Game of Choice: Patterns of Indian and Colonist Hunting in the Neotropics. American Anthropologist, 89 (3): 650-667.

Redford KH. 1992. The empty florest. BioScience, 42 (6): 412-422.

Reif JS. 2011. Animal Sentinels for Environmental and Public Health. Public Health Reports, 126 (Supplement 1): 50-57.

Reitz EJ, Wing ES. 2008. Zooarchaeology. 2 ed. Cambridge: Cambridge Univ Pr, 533p. 
Reo NJ, Whyte KP. 2012. Hunting and Morality as Elements of Traditional Ecological Knowledge. Human Ecology, 40 (1): 15-27.

Ribeiro D. 1998. O processo civilizatório: etapas da evolução sociocultural. São Paulo: Companhia das Letras.

Robinson JG, Redford KH. 1991. Neotropical wildlife use and conservation. 1 ed. Chicago: University of Chicago Press, 520 p.

Robinson MM, Zhang X. 2011. The World Medicines Situation 2011 - Traditional Medicines: Global Situation, Issues and Challenges. Geneva: Report of the World Health Organization.

Rocha-Mendes F, Mikich SB, Bianconi GV, Pedro WA. 2005. Mamíferos do município de Fênix, Paraná: etnozoologia e conservação. Revista Brasileira de Zoologia, 22 (4): 991-1002.

Rosa IL, Alves RRN, Bonifacio K, Mourão JS, Osorio F, Oliveira TPR. 2005. Nottingham, M. Fishers’ knowledge and seahorse conservation in Brazil. Journal of Ethnobiology and Ethnomedicine, 1 (1): 1-12.

Rosa IL, Oliveira TPR, Osório FM, Moraes LE, Castro ALC, Barros GML, Alves RRN. 2011. Fisheries and trade of seahorses in Brazil: historical perspective, current trends, and future directions. Biodiversity and Conservation, 20 (9): $1951-1971$.

Rovero F, Mtui AS, Kitegile AS, Nielsen MR. 2012. Hunting or habitat degradation? Decline of primate populations in Udzungwa Mountains, Tanzania: An analysis of threats. Biological Conservation, 146 (1): 89-96.

Santos-Fita D, Costa-Neto EM. 2007. As interações entre os seres humanos e os animais: a contribuição da etnozoologia. Biotemas, 20 (4): 99-110.

Santos-Fita D, Naranjo EJ, Rangel-Salazar JL. 2012. Wildlife uses and hunting patterns in rural communities of the Yucatan Peninsula, Mexico. Journal of Ethnobiology and Ethnomedicine, 3 (38): 1-17.

Sax B. 2002. The Mythological Zoo: An Encyclopedia of Animals in World Myth, Legend and Literature. Santa Barbara: ABC-CLIO - Inc, 339p.

Scanes, CG. 2003. Biology of growth of domestic animals. 1 ed. London: Wiley-Blackwell, 408p.

Scarpa A. 1981. Pre-scientific medicines: their extent and value. Soc Sci Med, 15 (1): 317-326.

Schenck M, Nsame Effa E, Starkey M, Wilkie D, Abernethy K, Telfer P, Godoy R, Treves A. 2006. Why People Eat Bushmeat: Results From Two-Choice, Taste Tests in Gabon, Central Africa. Human Ecology, 34 (3): 433-445.

Scotch M, Odofin L, Rabinowitz P. 2009. Linkages between animal and human health sentinel data. BMC veterinary research, 5 (1): 1-15.

Senior M. 2009. A cultural history of animals in the Age of Enlightenment. 1 ed. Berg: Berg Publishers, 256p.

Serpell JA. 2006. Animal-assisted interventions in historical perspective. In: Fine AH. (ed). Handbook on animal-assisted therapy: Theoretical foundations and guidelines for practice. 1 ed. San Diego: Academic Press, pp. 3-20.

Setten G. 2004. The habitus, the rule and the moral landscape. Cultural Geographies, 11 (4): 389-415.

Sexton C. 2011. The Bengal Tiger. 1 ed. London: Pilot Books, 24p. 
Shepard P. 1996. The Others: How Animals Made Us Human. 1ed. Washington (DC): Island Press, 2p.

Shiu H, Stokes L. 2008. Buddhist animal release practices: historic, environmental, public health and economic concerns. Contemporary Buddhism, 9 (2): 181-196.

Sifuna N. 2012. The Future of Traditional Customary Uses of Wildlife in Modern Africa: A Case Study of Kenya and Botswana. Journal of Biophysical Chemistry, 2 (1): 31-38.

Silvano RAM, Valbo-Jorgensen J. 2008. Beyond fishermen's tales: contributions of fishers' local ecological knowledge to fish ecology and fisheries management. Environment, Development and Sustainability, 10 (5): 657-675.

Silveira N. 1998. Gatos, a emoção de lidar. 1 ed. São Paulo: Editora Leo Christiano, 70p.

Singer P. 1993. Ética Prática. Lisboa: Faculdade de Letras da Universidade de Lisboa.

Singer P. 2004. Libertação Animal. Porto Alegre: Lugano, 357p.

Smith DM. 2000. Moral Geographies - Ethics in a World of Difference. Edinburgh: Edinburgh University Press, 272p.

Sousa RS. 2014. Espécie-chave cultural: uma análise dos critérios de identificação e de preditores socioeconômicos. 122f. PhD Botanic Thesis. Recife: Universidade Federal Rural de Pernambuco.

Souto WMS, Mourão JS, Barboza RRD, Alves RRN. 2011. Parallels between zootherapeutic practices in Ethnoveterinary and Human Complementary Medicine in NE Brazil. Journal of Ethnopharmacology, 134: 753-767.

Souto WMS. 2007. Zooterápicos utilizados na Etnoveterinária nos municípios de Cubati e Pedra Lavrada, Estado da Paraíba, Brasil. 72f. Bachelor's thesis in Biology. Campina Grande: Universidade Estadual da Paraíba.

Souza JB, Alves RRN. 2014. Hunting and wildlife use in an Atlantic Forest remnant of northeastern Brazil. Tropical Conservation Science, 7 (1): 145-160.

Spears NE, Mowen JC, Chakraborty G. 1996. Symbolic role of animals in print advertising: Content analysis and conceptual development. Journal of Business Research, 37: 87-95.

Steinhart EI. 1989. Hunters, poachers and gamekeepers: towards a social history of hunting in colonial Kenya. Journal of African History, 30 (2): 247-264.

Stephenson J. 1832. Medical zoology, and mineralogy, or Illustrations and descriptions of the animals and minerals employed in medicine, and of the preparations derived from them: including also an account of animal and mineral poisons. 1 ed. Detroit: John Wilson, 350p.

Sturtevant WC. 1964. Studies in Ethnoscience. American Anthropologist, 66 (3) Part 2: Transcultural Studies in Cognition, 99-131.

Sulman FG. 1982. Short and Long-Term Changes in Climate. 1 ed. Boca Raton: CRC Press.

Talukdar S, Gupta A. 2017. Attitudes towards forest and wildlife, and conservation-oriented traditions, around Chakrashila Wildlife Sanctuary, Assam, India. Fauna \& Flora International, 52 (3): 508-518. 
Taylor LH, Latham SM, Mark EJ. 2001. Risk factors for human disease emergence. Philosophical Transactions of the Royal Society of London. Series B: Biological Sciences, 356: 983-989.

Thirgood S, Mlingwa C, Gereta E, Runyoro V, Malpas R, Laurenson K, Borner M. 2008. Who pays for Conservation? Current and future financing scenarios for the Serengeti Ecosystem. In: Sinclair ARE et al. (eds.) Serengeti III - Human impacts on ecosystem dynamics. Chicago: University of Chicago Press, 443-469.

Thomas K. 1983. O homem e o mundo natural - Mudanças de atitude em relação às plantas e aos animais (15001800). São Paulo: Companhia das Letras, 544p.

Thomas WLJ. 1956. Man's Role in Changing the Face of the Earth. 1 ed. University of Chicago: Chicago Press, 1236p.

Tidemann S, Gosler A. 2010. Ethno-ornithology: Birds, Indigenous People, Culture and Society. 1 ed. Earthscan/ James \& James, 1232p.

Tomalin E. 2004. Bio-divinity and biodiversity: Perspectives on religion and environmental conservation in India. Article in Numen, 51(3):265-295.

Tonella LH, Conceição EO, Tonella C. 2016. Filosofia do Direito Ambiental: Os Animais Enquanto Sujeitos de Direito. Actio Revista de Estudos Jurídicos, 11 (26): 120-140.

Trinca CT, Ferrari SF. 2006. Caça em assentamento rural na Amazônia matogrossense. In: Jacobi P, Ferreira LC. (org.). Diálogos em ambiente e sociedade no Brasil. Indaiatuba: ANPPAS, Annablume, p. 155-167.

Trowell S. 2003. Drugs from Bugs: The Promise of Pharmaceutical Entomology. Futurist, 37 (1): 17-19.

Turner K, Freedman B. 2004. Music and environmental studies. The Journal of Environmental Education, 36 (1): 45-52.

Unnikrishnan E. 2004. Materia Medica of the Local Health Traditions of Payyannur. Discussion Paper No. 80, Kerala Research Programme on Local Level Development. Centre for Development Studies, 75p.

Unnikrishnan PM. 1998. Animals in Ayurveda. Amruth Suppl, 1 (1): 1-15.

Villafuerte R, Viñuela J, Blanco JC. 1998. Extensive predator persecution caused by population crash in a game species: the case of red kites and rabbits in Spain. Biological Conservation, 84 (2): 181-188.

Virgos E, Travaini A. 2005. Relationship between small-game hunting and carnivore diversity in central Spain. Biodiversity and Conservation, 14 (1): 3476-3486.

Vitali TR. 2010. But they can't shoot back - what makes fair chase fair? In: Kowalsky N. (Ed.). Hunting - Philosophy for Everyone: In Search of the Wild Life. Wiley- Blackwell, Chichester, pp. 23-32.

Voultsiadou E. 2010. Therapeutic properties and uses of marine invertebrates in the ancient Greek world and early Byzantium. Journal of Ethnopharmacology, 130 (2): 237-247.

Wennberg Digasper S. 2008. Natural resource management in an institutional disorder: the development of adaptive co-management systems of moose in Sweden. PhD Thesis. Luleå: Divisão de Ciências Políticas, Departamento de Administração e Ciências Sociais, Luleå University of Technology. 
Willebrand T. 2009. Promoting hunting tourism in north Sweden: opinions of local hunters. European Journal of Wildlife

Research, 55 (3): 209-216.

Woolhouse ME, Gowtage-Sequeria S. 2005. Host range and emerging and reemerging pathogens. Emerging Infections Diseases, 11(12): 1842-1847.

World Resources Institute - WRR. 2000. People and ecosystems the fraying web of life. Washington D.C.: Report World Resources Institute.

Wright SJ. 2003. The myriad consequences of hunting for vertebrates and plants in tropical forests. Perspectives in Plant Ecology, Evolution and Systematics, 6 (2): 73-86.

Yinfeng G, Xueying Z, Yan C, Di W, Sung W. 1997. Sustainability of wildlife use in Traditional Chinese Medicine. In: Mackinnon J, Wang S. (Eds.). Conserving China's Biodiversity: Reports of Biodiversity Working Group (BWG). China Environment Science Press, pp. 190-220.

Yoder, AE. 1947. Animal analogy in Shakespeare's character portrayal. 1 ed. King's Crown Press, 150p. 